\title{
Litteraturformidling og bibliotekaren som faglig - personlig formidlingsautoritet
}

\author{
Af Rasmus Grøn og Gitte Balling
}

\begin{abstract}
Denne artikel undersøger folkebibliotekarens rolle som litteraturformidler i lyset af det aktuelt dominerende oplevelsesrationale, hvor kommunikationen af personlige laeseerfaringer er blevet et uomgangeligt ideal for litteraturformidlingen. På baggrund af en spørgeskemaundersøgelse blandt danske folkebibliotekarer kortlagger artiklen, hvordan oplevelsesrationalet kommer til udtryk som en personliggørelse og socialisering af formidlingspraksissen på bibliotekerne. En tendens, som har ambivalente konsekvenser for bibliotekarens rolle og autoritet som formidler, idet denne både styrkes og relativeres. Afslutningsvis beskrives det, hvordan denne udvikling på sigt udfordrer bibliotekaren kompetencer og identitet som professionel formidler, og potentielt ekskluderer spørgsmålet om littercer kvalitet fra formidlingen.
\end{abstract}

Rasmus Grøn, adjunkt, ph.d., Aalborg Universitet (gron@hum.aau.dk)

Gitte Balling, adjunkt, ph.d., Det InformationsvidenskabeligeAkademi (gb@iva.dk)

\section{Indledning}

Evnen til at kommunikere med, appellere til og inddrage sine brugergrupper er de seneste årtier blevet et vigtigt parameter for folkebibliotekernes kvalitet og eksistensberettigelse. I forlængelse heraf er litteraturformidlingen blevet et centralt udviklingsområde, og kan siges at have overtaget materialevalgets plads som kerneaktiviteten i bibliotekernes praksis som litteraturinstitution (Grøn, 2010). Interessen for udvikling af litteraturformidlingen kan blandt andet aflæses $i$ en lang række lokale formidlingseksperimenter og -projekter på landets biblioteker (Styrelsen for Bibliotek og Medier, 2010; Grøn, 2010), ligesom man kan pege på det tværbibliotekariske litteraturformidlingssite Litteratursiden.dk (www.litteratursiden. $\mathrm{dk}$ ), væksten i antallet af litteraturfestivaler og bibliotekernes engagement i P2' s Romanlæseklub som regionale og landsdækkende eksempler.

Denne aktuelle indsats på formidlingsområdet er samtidig præget af hvad man kan kalde et oplevelsesrationale, (Grøn, 2010; Balling \& Kann-Christensen, 2010) ${ }^{1}$, idet der i hidtil uset grad fokuseres på litteraturen som ikke blot individuelt, men også socialt oplevelsesmedie, og hvor litteraturformidlingens former anskues som redskaber til at skabe og kommunikere litterære oplevelser. Dette rationale kommer til udtryk i to hovedformer:

Som 'formidling som oplevelse', hvor forskellige former for performative litterære aktiviteter iscenesættes i formidlingsrummet (oplæsninger, poetry slam, 
litteraturbingo, installationer m.v. $)^{2}$. Her er der tale om aktiviteter, hvor den litterære oplevelse løsrives fra læsesituationen og indlejres i formidlingens former som synkron med formidlingssituationen. Denne artikels fokus vil dog ligge på den anden hovedform, nemlig 'formidling om/af oplevelse', hvor den personlige læseoplevelse som et særligt aspekt ved den litterære reception tematiseres som formidlingens indhold i formidlingsgenrer som book-talks, læsekredse, anbefalinger og blogs.

At man som noget historisk nyt eksplicit inddrager den personlige læseoplevelse i bibliotekets (fysiske eller virtuelle) rum som indhold for formidlingen, kan ses som udtryk for en demokratisering af læsekulturen og rummer en række potentialer for blandt andet aktivering af brugerne som ressourcepersoner i formidlingen (Jochumsen og Hvenegaard Rasmussen, 2006). Men det skaber også en række udfordringer og behov for at gentænke formidlingens betingelser og formål. Det gælder ikke mindst relationen mellem formidlingens afsender og modtager, hvor bibliotekarens traditionelle position som litterær vidensautoritet udfordres af oplevelsesrationalets betoning af den individuelle læseoplevelse.

Det er disse forandringer i bibliotekarens formidlerrolle og relationer til formidlingens modtagere, som er emnet for artiklen, der bygger på følgende forskningsspørgsmål:

- Hvad betyder litteraturformidlingens aktuelle orientering mod en personlig oplevelseskontekst for bibliotekarens faglige rolle og kompetencer som formidler?

Efter en indledende begrebsafklaring vil artiklen ud fra et formidlingsteoretisk perspektiv beskrive den oplevelsesorienterede formidlings historiske fremvækst som en udvikling, der har påvirket såvel de forståelsesrammer, formidlingen sætter for tilgangen til litteraturen som relationen mellem formidlingens afsender og modtager.

De følgende afsnit vil ud fra resultaterne af en spørgeskemaundersøgelse blandt landets bibliotekarer analysere, hvordan formidlingen om/af oplevelse kommer til udtryk i formidlingspraksissen, hvordan det påvirker bibliotekarens rolle som formidler og læser, samt hvilke implikationer det har for bibliotekarens aktuelle selvforståelse og kompetencer som litteraturformidler. Slutteligt vil konklusionen samle op på artiklens pointer og kort diskutere det litterær kvalitetsbegrebs status i en formidling, som har den subjektive læseoplevelse som sit mål og middel.

Litterær oplevelse, litteraturformidling og formidlerroller og -relationer er fænomener, som langt fra kan belyses udtømmende inden for denne artikels rammer. ${ }^{3}$ Målet med artiklen er derfor, mere beskedent, at påpege og diskutere nogle af de udfordringer, som følger af formidling af og om litterær oplevelse. Diskussioner, som forhåbentlig kan danne udgangspunkt for videre undersøgelser. Det skal også understreges, at artiklens empiri kun inddrager et afsenderperspektiv i form af data indhentet blandt landets biblioteker. Undersøgelser som belyser ovennævnte problemstilling ud fra et brugerperspektiv vil utvivlsomt kunne nuancere, og måske også revidere, en række af denne artikels pointer, og vil derfor være et oplagt udgangspunkt for fremtidig forskning.

\section{Begrebsafklaring}

Mens formidlingsbegrebet vil blive behandlet i næste afsnit, viI vi her give en kort definition af artiklens to øvrige hovedbegreber: litteratur og oplevelse. Litteratur er i artiklen synonymt med skønlitteratur for voksne (og 'formidling af skønlitteratur for voksne' dækkes af den mere mundrette term 'litteraturformidling'), mens termen litterære tekster skal forstås i en bred, semiotisk forstand som et system af meningsgivende tegn (Chandler, 2007, s. 263ff). I modsætning til f. eks. 'bøger' knytter tekster sig dermed ikke til et bestemt medie, men kan også dække over virtuelle tekster og performative litterære udtryk som oplæsninger, poetry slam m.m.. Desuden indikerer 'tekst', til forskel fra 'titel' eller 'dokument', at skønlitteraturen i denne artikels optik ikke anskues som genstand for vidensorganisation eller udlån, men for læsning og oplevelse.

Ovennævnte oplevelsesrationale knytter sig på mange måder til det aktuelle hovedfokus på oplevelsesbegrebet inden for politiske, økonomiske og akademiske sfærer, der er opstået i kølvandet på teorierne om oplevelsessamfundet (Schulze, 1992) og oplevelsesøkonomien (Pine \& Gilmore, 1999). Fokus er i denne artikel dog afgrænset til litterær oplevelse som betegnelse for den individuelle læsers emotionelle og kognitive reaktion på en litterær tekst. Det er ikke målet her at analysere, typologisere eller vur- 
dere disse reaktioner (for en uddybende behandling af litterær oplevelse henvises til Balling og Grøns anden artikel i dette tidsskriftsnummer), men at pege på oplevelsen som den subjektive dimension ved den litterære erfaring, der er principielt ubundet af såvel objektive træk ved teksten som analyse - og kvalitetskonventioner i læserens omverden (Radway, 1997; Steffensen, 1993).

\section{Formidlingsbegrebet}

Formidlingsbegrebet dækker over kommunikative aktiviteter, der som fællesnævner indebærer viderebringelse af viden og/eller erfaring til en given modtager. Litteraturformidling lader sig på den baggrund forstå som en meget vidtstrakt praksis, hvor 'formidleren' udgøres af alle de aktører (institutioner, medier, privatpersoner), der videregiver litterære tekster eller viden om/ vurderinger af disse tekster til en modtager. I vores sociale liv udsættes vi løbende for henvisninger til, anbefalinger af og domme over litteratur, og private relationers påvirkning har vist sig at være en hovedfaktor i skønlitterære læseres bogvalg (Ross 2001).

'Formidling' anvendes dog primært (og også i denne artikel) til mere formelle kommunikationssituationer, som er kendetegnet ved et asymmetrisk vidensforhold mellem afsender og modtager, idet afsender formidler noget, som modtager ikke har eller ikke er vidende om. Derfor henviser formidlingsbegrebet typisk til relationer mellem institutioner og individer, hvor repræsentanter for en vidensinstitution formidler eksempelvis medicinsk (Elsass et. al 1997), journalistisk (Mikkelsen, 2002) eller akademisk viden (Flemming \& Ingemann, 2006) til en mindre vidende modtagergruppe. En definition, som naturligvis også dækker forholdet mellem folkebiblioteket som kulturinstitution og dets brugergrupper.

Asymmetrien mellem afsender og modtager er dog variabel, og afhænger ikke kun af vidensforholdet, men også af den institutionelle og historiske kontekst, hvori formidlingen finder sted. Man kan, lidt forenklet sondre mellem en autoritativ, vertikal formidlingsforståelse, der accentuerer asymmetrien og afsenders ekspertposition, og en mere kollaborativ, horisontal formidlingsforståelse, som tager udgangspunkt $i$ en mere ligeværdig relation mellem afsender og modtager (Grøn, 2010).
Formidling er desuden aldrig en neutral 'viderebringelse', men vil altid påvirke opfattelsen af formidlingens genstand. Litteraturformidling lader sig derfor definere som en praksis af performative kommunikationshandlinger (Austin, 1975), som i sin kommunikation om litteratur ikke blot tjener, men også altid påvirker mødet mellem modtager og litteraturen ved at stimulere til bestemte syn og interaktioner med litteraturen.

Den norske kunstsociolog Dag Solhjell (2001) taler om formidling som en kontekstualiserende aktivitet, der sætter bestemte forståelsesrammer for modtagerens iagttagelser af genstanden. I Solhjells formidlingsteori ${ }^{4}$ bringes disse forskellige kontekster til udtryk gennem paratekster ${ }^{5}$, forstået som den helhed af tegn, formidlerne anvender til at pege på værket (Solhjell, 2001). Og formidlingens tegn skaber et semiotisk rum mellem genstand og betragter, der som et filter eller 'prisme' udgør et uomgængeligt vilkår for den æstetiske oplevelse:

"Mellom kunstverkene og betrakteren er det er rom. Dette rommet er fylt av kunstformidling. Hver kunstformidler bærer et prisme. Betrakteren ser kunstverkene gjennom slike prismer, som bryter kunstverkene ned i ulike egenskaper og aspekter." (Solhjell, 2001, s. 15)

Litterære tekster kan principielt relateres til et utal af forskellige kontekster ${ }^{6}$, og det er formidlerens arbejde at selektere mellem de potentielle perspektiver, og skabe en fortolkningsramme ved at aktivere bestemte kontekster som for eksempel deres historiske tilhørsforhold, deres genremæssige slægtskab med andre tekster, forankring i bestemte tematikker m.v.. Men denne semiotiske proces trækker ifølge Solhjell på et kulturelt 'formidlingssprog', en række gældende konventioner for legitim beskrivelse og vurdering af litteraturen. Konventioner, der eksempelvis traditionelt dikterer, at læserens personlige livsverden ikke er en anerkendt kontekst i læsningen af kunstens tekster. Dermed placeres formidlingen i et antagonistisk forhold til den æstetiske oplevelse som subjektiv kategori, da den underkender såvel oplevelsens relevans som dens autenticitet, idet oplevelsen ses som uløseligt forbundet til den sociale semiosis, der definerer såvel tekstens som læserens kulturelle placering. Solhjell placerer sig hermed inden for en kritisk tradition i kunst - og litteratursociologien, hvor æstetisk reception defineres som altid allerede formet 
af sociale smags - og receptionsnormer, der bidrager til at reproducere kulturelle hierarkier (Bourdieu, 1997; Bürger, 1991).

\section{Litteraturformidling fra dannelses - til oplevelses- rationale}

Skal man trække en parallel til folkebiblioteket, så passer Solhjells beskrivelse ganske godt til dannelseskulturens formynderiske formidlingsrationale, hvor bibliotekaren så vidt muligt skulle sanktionere, at brugernes læsestof og læsemåder var i sync med institutionelt fastlagte kvalitetskriterier (Grøn, 2010). Men beskrivelsen synes dog langt fra dækkende i dagens oplevelsessamfund, hvor livets - og litteraturens - kvalitetskriterier overvejende forankres i den individuelle erfaring (Schulze, 1992) i en dyrkelse af 'sindets indre evidens' (Jantzen, 2006, s. 226). Den individuelle læsekultur er ubetvivleligt fortsat påvirket af sociale konventioner, men kan ikke længere ses som entydigt underlagt universelle normer for god læsning.

Denne bevægelse fra dannelses - og til oplevelsesrationale har naturligt nok også påvirket den bibliotekariske selvforståelse. Hvor bibliotekarens kulturformidleridentitet (Schreiber, 2006) tidligere var baseret på vurdering og formidling af kulturelle udtryk ud fra institutionelt sanktioneret viden, justeres denne identitet gradvist mod en differentieret kultur - og kvalitetsforståelse funderet i forskellige brugergruppers præferencer. Det fører til, at selve det kulturelle indhold får en mere sekundær betydning i forhold til brugerens udbytte af dette indhold, hvorfor man kan tale om et skifte fra en kulturformidler- til en oplevelsesformidlende identitet. (Ørom, 2006, s. 39) Læsning skal nu ikke legitimeres ud fra eksterne normer, men ud fra den enkelte læsers læselyst (van Riel \& Fowler, 1996), og formidlingens mål bliver derfor at styrke læserens tro på værdien af egen smag og læsevaner. Et billede, som blandt andet underbygges i Jofrid Karner Smidts norske undersøgelse af bibliotekarers litterære smag og selvforståelse (Karner Smidt, 2001), hvor de interviewede bibliotekarer afgrænser sig entydigt fra en akademisk smagsprofil, men har en væsentlig mere åben indstilling over for den populærkulturelle smag, som kendetegner flertallet af brugerne.

Denne anti-elitære formidleridentitet har dog historisk også medført en defensiv tilgang, hvor bibliote- karens rolle som formidlende vidensautoritet er blevet minimeret til fordel for et ideal om den neutrale bibliotekar, som i en distancering fra ethvert formynderi underspiller sin egen litterære kapitel (Karner Smidt, 2001) og udelader såvel personlige som institutionelle smagskriterier fra formidlingsarbejdet. Formidlingens opgave blev her ikke at udvide, udfordre og forme brugerens litterære horisont, men at udvælge og synliggøre litterære tekster på en måde, som tjente 'kundens' selvhjulpne opfyldelse af selvdefinerede behov (Jochumsen \& Rasmussen, 2006; Grøn, 2010).

Det aktuelle oplevelsesrationale ligger med sin emfase af litteraturens private betydning på mange måder i forlængelse af ovennævnte kundetænkning. Men samtidig er det som før nævnt også ledsaget af en vækst i formidlingsformer, hvor bibliotekarens oplevelsesformidlende identitet ikke blot knytter sig til den indirekte formidling af oplevelsesmedier ( $\mathrm{fx}$ litterære tekster), men til den direkte formidling og italescettelse af littercere oplevelser. En udvikling, som umiddelbart lægger op til en mere aktiv og offensiv formidlingsprofil. Men hvordan kommer dette til udtryk i bibliotekernes formidlingspraksis? Det er emnet for de følgende afsnit.

\section{Den personlige formidling}

Det følgende baserer sig på en elektronisk spørgeskemaundersøgelse af danske folkebibliotekers litteraturformidling foretaget i efteråret 2008. Undersøgelsen, som er den første af sin art, havde to hovedintentioner. For det første at kortlægge bibliotekernes aktuelle tilgange til og brug af centrale formidlingsformer. For det andet til at give nogle indikationer af hvilke holdninger til litteraturformidlingen og egen formidlerrolle, der ligger til grund for bibliotekarernes aktuelle formidlingspraksis.

Undersøgelsens population blev defineret som alle biblioteker med en ugentlig åbningstid på over 20 timer fordelt over min. 4 dage om ugen. Åbningstid blev anvendt som kriterium, da det antages at være en lettilgængelig indikator for bibliotekets aktivitetsniveau, og de anvendte kriterier syntes ud fra Biblioteksvejviserens oplysninger at være en gængs skæringsgrænse mellem hvad man kan kalde 'fuldtidsbiblioteker' og 'deltidsbiblioteker' (Danmarks Biblioteksforening, 2008). Det resulterede i en population på 291 danske folkebiblioteker, hvoraf 187 be- 
svarede skemaet. Svargruppen var ud fra faktorerne geografi, demografi og bibliotekstype (lokal -, hoved - og centralbiblioteker) repræsentativ i forhold til populationen, ligesom skemaerne alle blev udfyldt af ansatte med formidlingsansvar, som derfor var formelt kompetente til at besvare spørgsmålene. Det er dog vigtigt at huske, at respondenterne ikke er 'biblioteker', men individuelle biblioteksrepræsentanter, hvorfor undersøgelsen heller ikke er repræsentativ, da svargruppen kun udgør en lille procentdel af den samlede population af relevante folkebibliotekarer.

Af hensyn til svartiden blev skemaets spørgsmål overvejende udformet med lukkede spørgsmål (primært Likert - skala) med tilhørende kommentarbokse. Dog med væsentlige undtagelser, idet to indledende spørgsmål om aktuelle ændringer i formidlingens omfang og karakter blev fastholdt som åbne spørgsmål. Det blev gjort for at yde emnet retfærdighed, idet informationsværdien er meget begrænset, hvis man ikke spørger til hvordan formidlingens omfang og karakter har forandret sig. Samtidig er de potentielle variabler så mangfoldige, at det ikke er muligt at dække dem med diskrete afkrydsningskategorier. Og det er særligt besvarelserne af disse to åbne spørgsmål, som i første omgang vil være udgangspunkt for analysen.

Besvarelserne bekræftede næsten enstemmigt, at der pt. sker en øget investering i litteraturformidlingen, som samtidig undergår en række signifikante kvalitative forandringer. Man kan ud fra dataene her udsondre personliggørelse og socialisering som de to mest centrale tendenser i denne forandringsproces. Det er tendenser, som begge knytter sig til oplevelsesrationalet og sætter bibliotekarens formidlerrolle og brugerrelation i spil på nye, tvetydige måder.

Den første tendens i besvarelserne var orienteringen mod en mere personlig og aktiv formidling, hvor man i dag har brudt med den førnævnte neutrale bibliotekarfunktion, som tidligere har præget bibliotekernes formidlingsforståelse til fordel for en mere opsøgende formidlerrolle, hvor bibliotekaren investerer sig selv som person og læser i formidlingen:

"[Formidlingen] er blevet mere offensiv, direkte og personlig [...] Vi er blevet mere bevidste omkring at lånerne har behov for at blive guidet til læsning af romaner [...]Vi er blevet mere udfarende, det er ikke svært at få personalet til at formidle egne læseoplevelser." (Grøn 2010, s. 107)

Denne 'guidning' dækkede i flere tilfælde ikke blot en organisering af materialer, som understøtter brugerens vej til læsningen, men også guidning $i$ læsning, hvor bibliotekaren gennem personlige anbefalinger søger at kvalificere brugernes læsevalg og læseoplevelser. Personliggørelsen af formidlingen viser sig konkret blandt andet i en større grad af personlig brugervejledning og i form af den personlige signatur på skriftlige formidlingsgenrer såsom anbefalingen.

Anbefalingen er primært en digital genre, og virtualiseringen fremhæves naturligt nok som en hovedfaktor i denne sammenhæng. Den virtuelle formidling undergår dog en markant centralisering i disse år, hvor den primært praktiseres som bidrag til den landsdækkende hjemmesiden litteratursiden.dk, og derfor ikke sker på bekostning af den lokale, fysiske formidling (Grøn, 2010, s. 102-3) Her er det især book-talks, eller bog - og litteraturcaféer, hvor bibliotekaren gennem den direkte henvendelse til en gruppe af personer orienterer om og anbefaler litteratur, der fremhæves som en formidlingsaktivitet $\mathrm{i}$ stærk vækst ${ }^{7}$ :

"Bogcafé, hvor bibliotekarer fortæller om og anbefaler bøger, er forholdsvis nyt og meget populær [...] Tidligere lavede vi kun bogudstillinger. $\mathrm{Nu}$ afholder vi 2 gange om året bogcafeer, hvor vi fortæller om bøger vi har læst. Personalet anmelder på skift en bog på vores hjemmeside (månedens bog)." (Grøn, 2010, s. 108)

Book-talks er i modsætning til traditionelle litterære arrangementer kendetegnet ved deres interne karakter, idet de arrangeres og afholdes af bibliotekarerne selv. Prioriteringen af book-talks peger derfor på en ny iscenesættelse af bibliotekaren som litterær autoritet, der påtager sig den rolle, som før var forbeholdt repræsentanter for andre institutioner i det litterære kredsløb (kritikere, forskere $\mathrm{m}$ fl.). Og som det blandt andet fremhæves i nedenstående citat, så hænger denne styrkede autoritet også sammen med en holdningsændring hos brugerne, som i højere grad værdsætter og også opsøger bibliotekarens vejledning: Personalet satter egen person på spil. Det er $i$ orden at gå direkte til folk og sige "Det her er lige en bog for dig." (Grøn, 2010, s. 107). 
Det er i høj grad bibliotekarens 'person', som fremhæves hos respondenterne, hvorfor undersøgelsens udsagn peger på, at den øgede kontakt med brugerne er funderet på personlige litterære erfaringer og holdning snarere end faglig smagsautoritet.

En anerkendende tilgang til lånerne ledsages således tilsyneladende af en ny bibliotekarisk formidleridentitet, hvor forholdet mellem bibliotekaren og låneren i højere grad opleves som en personlig end som en institutionel relation (Balling, Henrichsen, Skouvig, 2008; Johannsen, 2009). Dette billede bekræftes i en aktuel interviewundersøgelse blandt formidlingsansvarlige på en række centralbiblioteker (Balling og Kann-Christensen, 2010), hvor brugerorienteringen fremhæves som en fællesnævner for den aktuelle formidlings værdier og mål, der dækker over en række vidt forskellige mål og rationaler. Litteraturformidlingen er ifølge undersøgelsen i mindre grad fokuseret på den litteratur, som formidles end på selve aktiviteten, dialogen, den sociale event, der alt sammen har som formål at tilfredsstille brugernes behov. Man kan derfor sige, at låneren eller brugeren i høj grad opfattes som en kunde, men at dette brugerfokus går hånd $\mathrm{i}$ hånd med en meget personlig tilgang til formidling, hvor formidlerens egen smag, litterære præferencer og oplevelseskriterier ofte fremhæves i interviewene:

"Thus the quality of the event is connected to users accept and interest in the promoters personal taste ("it's just so nice"). Nowhere in the interviews are justifications for personal taste given. This could indicate that the personal taste and reading pleasure of the promoter has a role to play in literature promotion." (Balling \& Kann-Christensen, 2010, s. 12)

Dette fokus på personlig oplevelse i litteraturformidlingen er ifølge den amerikanske medieforsker Jim Collins (2010) et hovedtræk ved den aktuelle litterære kultur, som på den ene side er kendetegnet ved en afvisning af traditionelle smagsnormer til fordel for et subjektivistisk læseideal, hvor selv kanoniserede litterære tekster læses ud fra personlige relevanskriterier. På den anden side har litteraturen og den litterære oplevelse, trods denne relativering, bevaret sin kulturelle aura som en både almengyldig og unik, kultiverende erfaring. Derfor praktiseres den populære formidling i dag i stigende grad uden for de litteraturkritiske institutioner og afviser analytiske læse- modi og normativ differentieringer mellem læsninger til fordel for en dyrkelse af den litterære oplevelses uangribelige værdi (Collins, 2010, s. 85ff). Formidlerens primære roller bliver her dels at foretage en præselektion i det uoverskuelige kakofoni af litterære titler, og præsentere disse titler som læseoplevelser, der er i øjenhøjde med den menige læsers horisont; dels (og hermed) at fungere som ceremonimester og inspirator for et (fysisk eller abstrakt) fællesskab af oplevende læsere. Formidlerens autoritet legitimeres i tråd hermed ikke så meget i vedkommendes institutionelle og faglige ekspertise som i hendes status som inspirerende 'superlæser', hvis identitet er forankret i det læsende fællesskab. (Collins, 2010)

Og et samlende træk ved den personlige formidling, som den fremstilles af spørgeskemaundersøgelsens informanter, er netop udgangspunktet i og orientering mod læseoplevelsen, hvor idealet er italesættelsen og udveksling af personlige litterære erfaringer:

"Det er blevet mere legalt at anbefale fra hjertet $(1 / 2)$ der er kommet større fokus på skønlitteraturen fra lånernes side, forstået på den måde at læsning ikke længere udelukkende er en privat sag, men at man gerne vil dele sine læseoplevelser med andre i større eller (især) mindre grupper." (Grøn 2010, s. 108-9)

Disse mindre grupper er ofte læsekredse, der aktuelt oplever en renæssance (Lund, 2006) som et eksempel på en social, oplevelsesorienteret formidlingsform. Men læsekredse er blot ét af flere eksempler på, at den personlige formidling også er forbundet med en socialisering af formidlingen. Besvarelserne vidner således om en udstrakt brug af formidlingsformer som bogstafetter, 'fra låner til låner' m.fl., hvor biblioteket fra at være formidlingens afsender bliver en offentlig scene, som faciliterer 'menige' læseres kommunikation og udveksling af private læseoplevelser. Og på denne scene bliver rollefordelingen flydende, idet formidleren ikke blot optræder som læser; læseren bliver til tider også formidler:

"...en mere direkte formidling - fra personale til låner, fra låner til låner. Vi er begyndt at afholde litteraturcaféer. Vi opsøger lånerne uopfordret og anbefaler bøger. Lånerne anbefaler også bøger til os." (Grøn, 2010, s. 108) 
Formidlingens sociale relation får således karakter af et 'oplevelsesfællesskab', hvor den personlige formidling knyttes til dialogiske formidlingsformer, som ikke kun er brugerorienterede, men også på forskellig vis aktiverer og inddrager brugerne.

Undersøgelsens resultater indikerer således, at oplevelsesrationalet på den ene side tildeler bibliotekaren en mere aktiv formidlerfunktion, men på den anden side relativerer denne funktions traditionelle forankring i den autoritative rolle som vidensekspert og smagsgarant, idet formidler og modtager i højere grad ligestilles i et fællesskab af læsende subjekter. Bibliotekarens autoritative formidlerrolle udfordres således af en formidlingsforståelse, som nivellerer formidlingsrelationens asymmetri til fordel for en horisontal udveksling af læseoplevelser. En forståelse, som med formidlingens socialisering tenderer mod at opløse grænserne mellem formidlingens afsender og modtager, og mellem den brede og smalle forståelse af formidling (jf. afsnit om 'Formidlingsbegrebet'), idet bibliotekarens funktion forvandles fra formidler til facilitator af brugernes indbyrdes kommunikation. Men hvordan relaterer denne formidlingssituation sig til bibliotekarernes (selv)forståelse af egne kompetencer - og de faktuelle betingelser for disse kompetencer?

\section{Bibliotekarens formidlingskompetencer}

I spørgeskemaundersøgelsen beskriver en række informanter den nye, mere aktive og opsøgende formidlerrolle som en faglig kompetence, der er blevet udviklet gennem deltagelse i formidlingsrelaterede kurser. Men for flertallets vedkommende er der tale om en mere intuitiv kompetence, hvor en holdningsændring blandt både brugere og biblioteker gør, at den udfarende tilgang gennem vejledning, anbefalinger, book-talks m.m. opleves som mere naturlig.

Ud over disse kommentarer blev undersøgelsens informanter også spurgt konkret om deres vægtning af faglige kompetencer i litteraturformidlingen:

Flere biblioteksforskere har peget på, at den bibliotekariske formidlerrolle fordrer flere kompetencer. Åse Tveit (2004) sondrer fx mellem: 1) Sociologiske kompetencer, i form af kendskab til modtagernes smag og forudsætninger; 2) Littercere kompetencer, i form af overblik over samlingen, struktureret viden om litterære begreber og tendenser og et 'reservoir' af litterære referencer; 3) Kommunikative kompetencer som evnen til at artikulere sin viden i en form, der er tilpasset den givne læser eller gruppe af læsere. ${ }^{8}$

På baggrund af formidlingens aktuelle personliggørelse og oplevelsesfokus, og tidligere undersøgelsers afdækning af bibliotekarers store forbehold over for litterære vidensautoriteter (Karner Smidt, 2001) kunne man have formodet, at de sociologiske kompetencer ville blive vurderet som vigtigere end litterær viden. Men sådan forholdt det sig ikke, idet undersøgelsens informanter anså litterær viden for den klart vigtigste kompetence i formidlingsarbejdet. De ovennævnte kategorier kan dog være gensidigt betingede, idet 'skønlitterær viden' har en vis semantisk åbenhed, og kan relateres til såvel sociale kompetencer (viden om brugernes læsevaner) som til informationssøgningskompetencer (viden om litteraturens repræsentation i informationsarkitekturen). Derfor blev der indført et kontrolspørgsmål (andet spørgsmål nedenfor) hvor tilføjelsen af 'faglig' skulle give begrebet litterær viden en mere forpligtende karakter:

\begin{tabular}{|c|c|c|c|c|c|c|}
\hline & $\begin{array}{l}\text { 1. Størst } \\
\text { betydning }\end{array}$ & $\begin{array}{l}\text { 2. Næst } \\
\text { størst } \\
\text { betydning }\end{array}$ & $\begin{array}{l}\text { 3. Tredje } \\
\text { størst } \\
\text { betydning }\end{array}$ & $\begin{array}{l}\text { 4. Fjerde } \\
\text { størst } \\
\text { betydning }\end{array}$ & $\begin{array}{l}\text { 5. Femte } \\
\text { størst } \\
\text { betydning }\end{array}$ & Total \\
\hline Litterær viden & 99 & 51 & 20 & 5 & 1 & 176 \\
\hline Personligt kendskab til brugerne & 36 & 42 & 47 & 34 & 16 & 175 \\
\hline Informationssøgningskompetencer & 14 & 37 & 47 & 57 & 20 & 175 \\
\hline Sociale kompetencer & 27 & 42 & 49 & 52 & 5 & 175 \\
\hline Skriftlige kompetencer & 0 & 3 & 12 & 27 & 133 & 175 \\
\hline
\end{tabular}

Tabel 1. Grøn 2010, s. 150 


\begin{tabular}{|l|c|c|c|c|c|c|}
\hline & $\begin{array}{c}\text { Meget } \\
\text { uenig }\end{array}$ & uenig & $\begin{array}{c}\text { Både } \\
\text { og }\end{array}$ & Enig & $\begin{array}{c}\text { Meget } \\
\text { enig }\end{array}$ & Total \\
\hline $\begin{array}{l}\text { Aktiv deltagelse i materialevalg er en betingelse for kompetent } \\
\text { formidling }\end{array}$ & 8 & 36 & 59 & 41 & 33 & 177 \\
\hline $\begin{array}{l}\text { Litteraturfaglig viden er en betingelse for kompetenceudvikling } \\
\text { som formidlere af skønlitteratur }\end{array}$ & 1 & 14 & 45 & 94 & 25 & 179 \\
\hline Bibliotekaren kender sine låneres skønlitterære behov & 1 & 10 & 59 & 89 & 19 & 178 \\
\hline
\end{tabular}

Tabel 2. Grøn 2010, s. 151

Besvarelserne giver et næsten identisk resultatet og det må derfor konstateres, at litteraturfaglig viden ifølge undersøgelsen tillægges en primær rolle i bibliotekernes formidlingsarbejde.

Kendskabet til brugernes behov er et kernepunkt i den bibliotekariske selvforståelse, som bidrager til at positionere biblioteket i det kulturelle felt: Bibliotekets litteraturformidling er ikke baseret på teoretiske antagelser eller idealer, men på kendskabet til den almene læsers potentialer og behov (Tveit, 2004; Jochumsen \& Rasmussen, 2006). Men biblioteket er samtidig en institution med en meget differentieret brugergruppe, hvorfor spørgsmålet kan være svært at besvare entydigt. En tredjedel af respondenterne svarer således også Både og til spørgsmålet, og der er en klar tendens til, at svarene fordeler sig proportionelt efter bibliotekstype, hvor mindre biblioteker med mere overskuelige brugergrænseflader forholder sig mere positivt til eget brugerkendskab.

Hvor der er bred konsensus omkring Brugerkendskab og Litteraturfaglig viden, forholder det sig anderledes med holdningen til materialevalgsdeltagelse som betingelse for kompetent formidling. Her er der en svag positiv tendens, men også stor dissensus: præcist en 1/3 af respondenterne svarer Både og, 42 $\%$ er Enige/Meget Enige, mens $26 \%$ er Uenige/Meget uenige. Denne store spredning skal ses i lyset af den aktuelt udbredte rationalisering af materialevalget på landets biblioteker i form af interne centraliseringer eller udliciteringer til andre aktører. Hermed tages materialevalget ud af den menige bibliotekars hænder, og der sker en autonomisering af formidlingen, som realt løsrives fra bogvalgsprocessen.

Det har affødt en materialevalgsdebat (Frandsen, 2001; Lerche, 2005; Kristiansson \& Enemærke, 2005), som grundlæggende har udspillet sig mellem to fløje: På den ene side en modstanderfløj, som ud fra en 'videnslogik', hævder, at det kendskab til bestandens tekster, som kommer af et aktivt materialevalg, er grundlæggende for en kompetent formidling af disse tekster. På den anden side en tilhængerfløj, som ud fra en 'arbejdsdelingslogik' ikke anskuer materialevalg og formidling som gensidigt betingede, men tværtimod som komplementære, hvorfor udliciteringen af det tidskrævende materialevalg kan skabe mere tid og rum for en udvidet formidlingsindsats. ${ }^{9}$

Ud over den principielle frygt for en øget standardisering af det litterære udbud rejser det et konkret vidensspørgsmål: Kan man formidle skønlitteratur uden at have nogen større viden om det, man formidler? En problematik, som forstærkes med litteraturundervisningens de facto afvikling på biblioteksstudiet, og potentielt medfører, at forankringen af formidlingen i personlige læseoplevelser bliver et tvungent vilkår frem for en fagligt underbygget strategi.

\section{Konklusion og afsluttende bemærkninger}

Den aktuelle litteraturformidling på folkebibliotekerne er præget af en orientering mod oplevelser, både forstået som formidling som oplevelse, hvor litteraturformidlingen iscenesættes inden for nogle ekstraordinære rammer, der skaber et ekstra oplevelseslag hos beskueren, og forstået som formidling om/ af oplevelse, hvor der mere indirekte fokuseres på italesættelsen og formidlingen af selve den personlige læseoplevelse.

Udgangspunktet for denne artikel var at undersøge hvordan sidstnævnte tendens har påvirket bibliotekarernes formidling og formidleridentitet. Artiklens resultater peger på, at den oplevelsesorienterede litteraturformidling er kendetegnet ved en bevægelse væk fra en vertikal autoritativ formidling og hen imod en mere horisontal kollaborativ formidlingsforståelse. 
Det kommer for det første til udtryk i en personliggørelse af formidlingen, hvor bibliotekaren indtager en mere aktiv og offentlig formidlerrolle, som dog i mindre grad baserer sig på faglig viden og institutionel autoritet end på formidlerens personlige investering og erfaring som læser. Læserne efterspørger ikke primært bibliotekarens faglige viden, men netop deres personlige erfaringer som læsere. For det andet sker der også en stigende socialisering af formidlingen som et forum for udvekslinger af personlige læseoplevelser mellem ligestillede læsere. En tendens, som udvisker grænserne mellem såvel institutionel og privat formidling som mellem formidler og modtager, og betoner bibliotekets rolle som scene for denne kommunikation.

Artiklens undersøgelsesresultater tegner et ambivalent billede af den oplevelsesorienterede litteraturformidlings betydning for bibliotekarens formidling og formidlerrolle. På den ene side er den udtryk for en demokratisering af den litterære kultur, der vitaliserer den litterære samtale i det offentlige rum - og samtidig tildeler bibliotekaren en aktiv formidlingsfunktion, som bryder med rollen som neutral servicemedarbejder. På den anden side rejser den også en række udfordringer vedrørende denne identitet, som afsluttende skal fremhæves.

For det første kan man spørge hvad det stærke fokus på den personlige oplevelse og nedtoningen af bibliotekarens institutionelle autoritet viden betyder for den bibliotekariske profession? Hvis formidlerrollen ændres fra autoritativ ekspert til en ligeværdig læser, hvis viden om litteratur bunder i personlig læselyst, hvori ligger så det professionelle? At dette møde mellem læsere kan være frugtbart, skal der ikke sås tvivl om. Spørgsmålet er blot, om man nødvendigvis behøver at være bibliotekar for at udfylde denne rolle eller om den i praksis kunne udfyldes af andre superlæsere? Men andre ord: hvad - om noget - legitimerer bibliotekarens fremtidige rolle som formidler i forhold til andre formidlere/læsere?

Artiklens empiriske grundlag peger ganske vist på, at bibliotekarerne i høj grad ser den personlige formidlerrolle som baseret på en faglig litterær viden. Men det er samtidig en viden, som har mistet sin forankring i såvel den bibliotekariske praksis som uddannelse, idet den markante prioritering af faglig litterær viden som formidlingskompetence modsvares af den aktuelle reduktion af denne viden. Den stigende efterspørgsel på bibliotekarens personlige smagspræferencer og læseoplevelser ledsages således af en stigende formel svækkelse af bibliotekarens litteraturfaglige platform, hvorved bibliotekaren gradvist forvandles til en professionel litteraturformidler, hvis litterære kompetencer paradoksalt nok afhænger af hans/hendes private læseengagement.

En anden udfordring ved en formidling, som finder sted i et læsende oplevelsesfællesskab er, at kvalitetsdiskussioner vanskeliggøres eller sågar forstummer. I bevægelsen hen imod den personlige læseoplevelse sker der en bevægelse væk fra værket, fra den litterære tekst. I en formidlingskontekst som italesætter den personlige oplevelse, fokuseres opmærksomheden på læsningen som forankret i en subjektiv livs - og erfaringsverden, der bygger på individuelle smags - og relevanskriterier, og hvor tekstens kvalitet handler om hvilke oplevelser læsningen har bibragt læseren. Hvorvidt den litterære tekst er af høj litterær kvalitet er ikke alene af mindre relevans i en oplevelsesorienteret læseforståelse, men er sågar vanskeligt at diskutere, da det vil true anerkendelsen af læsningen som altid ligeværdig kulturel aktivitet.

Disse udfordringer må - i hvert fald på længere sigt - vække eftertanke i forhold til bibliotekarernes professionelle rolle som formidlere og bibliotekets rolle som kulturinstitution.

\section{Noter}

1. Dette oplevelsesrationale udgør en gennemgribende tendens, som ud over litteraturformidlingen også vedrører fx arkitektoniske oplevelser, i form af spektakulært og udfordrende biblioteksdesign og sociale oplevelser, med investeringer i biblioteket som socialt mødested m.m.. (Niegaard et. al., 2008; Jochumsen og Hvenegaard Rasmussen, 2008)

2. For mere herom, se bl.a. Lise Kloster Grams artikel Er biblioteket performancelitteraturens omslag? i Nordisk Tidsskrift for Informationsvidenskab og Kulturformidling, vol.1/2, 2012, s. 81-91.

3. Artiklen bygger delvist på forfatternes ph.d. afhandlinger, og der henvises hertil for uddybende undersøgelser og diskussioner af artiklens hovedbegreber (Balling, 2009; Grøn, 2010). 
4. Solhjells teori knytter sig til kunstformidling, men lader sig med udbytte oversætte til litteraturformidlingen. Der er dog også æstetiske og institutionelle forskelle mellem billedkunst og litteratur, som sætter grænser for denne oversættelse. Se Grøn 2010, s. 68-69

5. Paratekstbegrebet henter Solhjell hos Gerard Genette (Genette, 1987), men redefinerer det situationelt, som alle de tekster og fænomener, der anvendes som betydningsbærende tegn i et formidlingsrum.

6. Solhjell sondrer selv mellem dels karakteriserende og vurderende kontekster, dels æstetiske kontekster (hvor der fx henvises til værker af samme eller andre kunstnere, æstetiske retninger m.m.), og ikke-æstetiske kontekster (hvor værket relateres til fx sociale, historiske, biografiske eller politiske kontekster). (Solhjell, 2001, s. 120-50)

7. For eksempler på book talk - og bogcaféprojekter, se Lerche, 2005; Eggertsen et. al., 2007

8. I an analog tredeling definerer Jens Thorhauge (Thorhauge, 1995) bibliotekarens centrale formidlingsroller som: 1) Kritikeren og litteraten, der har en bred viden om det litterære domæne og evnen til kritisk læsning og analyse; 2) Socialantropologen, som har indsigt i såvel kulturelle og demografiske forhold i bibliotekets omverden, som den enkelte brugers horisont og forudsætninger; 3 ) Pcedagogen og markedsføreren, som kan tilpasse sig forskellige brugergruppers behov og synliggøre bibliotekets tilbud for disse.

9. En holdning, som kommer eksplicit til udtryk hos en central interessent, Dansk Bibliotek Center, som netop markedsfører deres service Materialevalg + under sloganet 'Flere ressourcer til formidling' (http://materialevalg07.dbc.dk/?Page=6).

\section{Referencer}

Austin, JL (1975). How to do Things with Words. [the William James Lectures delivered at Harvard University in 1955] (2. udg.). Cambridge (MA): Harvard University Press.

Balling, G \& Kann-Christensen, N (2010). Using the user: Notions on literature promotion in Danish pub- lic libraries. Paper presented at Nordic conference on public library research, Oslo.

Balling, G (2009). Littercer cestetisk oplevelse. Loesning, loeseoplevelser og loeseundersøgelser: en diskussion af teoretiske og metodiske tilgange. (Ph.d. afhandling) København: Danmarks Biblioteksskole.

Balling, G, Henrichsen, LA \& Skouvig, L (2008). Digital reading groups: renewing the librarian image. New Library World, Vol. 109, Issue 1-2, 56-64.

Bourdieu, P (1997): Men vem har skapat skaparna? I: L. Furuland \& J. Svedjedal (eds.). Litteratursociologi. Texter om litteratur och samhälle. (s. 133-45) Lund: Studentlitteratur.

Bürger, P (1991). Institusjonen kunst som litteratursosiologisk kategori. I: A. Kittang et. al. (eds.). Moderne litteraturteori. (s. 332-58) Oslo: Universitetsforlaget.

Eggertsen, T, Rasmussen, OH \& Wengel, L (2007). Café-indsats for læsning og læseoplevelser i Aalborg. Danmarks Biblioteker, vol. 4, 14-16.Chandler, D (2007). Semiotics: the basics. New York: Routledge.

Collins, J (2010). Bring on the books for everybody. How literary culture became popular culture. Durham and London: Duke University Press.

Danmarks Biblioteksforening (2008). Biblioteksvejviseren 2007-08. København: Danmarks Biblioteksforening

Elsass, P, Olesen, F \& Henriksen, S (eds.) (1997). Kommunikation og forståelse - kvalitative studier af formidling og fortolkning i sundhedssektoren. Århus: Forlaget Philosophia.

Flemming, R \& Ingemann, B (eds.) (2003). Faglig formidling - praksis og konsekvenser. Roskilde: Roskilde Universitetsforlag.

Frandsen, K (2001). Materialevalget og bibliotekarrollen. Bibliotekspressen, vol. 18, 522.

Genette, G (1987). Paratexts. Thresholds of interpretation. Cambridge: Cambridge University Press. 
Gram, LK (2012). Er biblioteket performancelitteraturens omslag?

Grøn, R (2010). Oplevelsens rammer. Formidling af skønlitteratur for voksne på danske folkebiblioteker. (Ph.d. afhandling). Aalborg: Danmarks Biblioteksskole.

Jantzen, C (2006). Oplevelsesincitamentet. Den moderne hedonismes historiske forudsætninger. I: Eriksson, B et al (eds.). Smagskulturer og formidlingsformer (s. 215-40). Århus: Klim

Jochumsen, H \& Hvenegaard Rasmussen, C (2006). Bibliotekets brugere - fra klienter til forandringsagenter. I: Emerek, L et. al. (eds.). Folkebiblioteket som forvandlingsrum. Perspektiver på folkebiblioteket $i$ kultur - og medielandskabet.(s. 41-53) København: Danmarks Biblioteksforening.

Jochumsen, H \& Hvenegaard Rasmussen, C (2008). Ej blot til oplysning. Folkebiblioteket i oplevelsessamfundet. I: Andersen, J et. al. (eds.). At forstå biblioteket. En introduktion til teoretiske perspektiver (s. 159-89). København: Danmarks Biblioteksforening.

Johannsen, CG (2009). Folkebibliotekernes brugerbilleder. 4 forestillinger om brugeren. Dansk Biblioteksforskning, årgang 5, nr. 1, 5-16.

Karner Smidt, J (2002). Mellom elite og publikum. Litterær smak og litteraturformidling blant bibliotekarer i norske folkbibliotek. Oslo: Unipub forlag.

Kristiansson, MR \& Enemærke, M (2004). Det specialiserede materialevalg. Bibliotekspressen, vol. 16, 470-71.

Lerche, A (2005). Bibliotekar med klassiske dyder. Bibliotekspressen, vol. 11, 17-18.

Lund, ND (2006). Skønlitterære læsekredse - mellem livsverden, marked og folkebibliotek. I: Emerek, L et. al. (eds.). Folkebiblioteket som forvandlingsrum. Perspektiver på folkebiblioteket $i$ kultur - og medielandskabet.(s. 105-19) København: Danmarks Biblioteksforening.

Mikkelsen, JF (2002). Formidlingsetik. Roskilde: Roskilde Universitetsforlag.
Niegaard, H, Lauridsen, J \& Schulz, K (eds.) (2008). Biblioteksrummet: inspiration til bygning og indretning. København: Danmarks Biblioteksforening.

Pine, JB \& Gilmore, JH (1999). The Experience Economy. Boston: Harvard Business Press

Radway, JA (1997). A Feeling for Books (The Bookof-the-Month-Club, Literary Taste, and Middle-Class Desire). Chapel Hill: University of North Carolina Press

Ross, CS (2001). Making choices: what readers say about choosing books to read for pleasure. Acquisitions Librarian, 13/25, 5-22.

Schreiber, T (2006). Bibliotekarprofessionen siden 1960erne. I: Elbeshausen, H \& Schreiber, T (eds.). Bibliotekarerne - en profession i et felt af viden, kommunikation og teknologi. (s. 15-47) København: Forlaget Samtidslitteratur

Schulze, G (1992). Die Erlebnisgesellschaft. Kultursoziologie der Gegenwart. Frankfurt: Campus Verlag.

Solhjell, D (2001). Formidler og formidlet. Oslo: Universitetsforlaget.

Steffensen, B (1993). Når børn loeser fiktion Grundlaget for en ny litteraturpcedagogik. København: Akademisk Forlag

Styrelsen for Bibliotek og Medier (2010). Folkebibliotekerne $i$ vidensamfundet. Rapport fra Udvalget om folkebibliotekerne $i$ vidensamfundet. København: Styrelsen for Bibliotek og Medier. Lokaliseret d. 24. april 2010 på: http://www.bibliotekogmedier.dk/fileadmin/publikationer/rapporter_oevrige/folkebib_i_ vidensamfundet/pdf/Folkebib___videnssamf.pdf

Thorhauge, J (1995). Luk op for skønlitteraturen om skønlitterær formidling i folkebiblioteker. I: Pedersen, EM (ed.). Litteratursociologi (2.udg.) (s.17389). København: Bibliotekscentralens Forlag.

Tveit, Å (2004). Innganger - om lesning og litteraturformidling. Bergen: Fagbokforlaget.

Van Riel \& Fowler, O (1996). Opening the bookfinding a good read. West Yorkshire: Opening the Book. 